\title{
III. 病因と病態一最近の遺伝子解析を中心に
}

\section{田中 真二}

要旨

肝細胞癌 (肝癌) の多くは, 慢性肝炎, 肝硬変を背景として発生し, 異形成結節, 早期肝癌の段階を経 て, 脱分化によって進行肝癌へと至る，いわゆる多段階発癌のプロセスを辿ることが知られている. 多段 階プロセスの分子メカニズムについて様々な研究がなされているが, 昨今のゲノムワイドな遺伝子解析に よって，その全容が明らかになりつつある，本稿では，特に蓄積が進んでいるゲノムのビッグデー夕に基 づいた新しい知見を紹介し, 肝癌の病因と病態について概説する.

〔日内会誌 $103 ： 19 \sim 26,2014]$

Key words 多段階発癌, GWAS, 全ゲノムシーケンス, クロマチン構造変換, 酸化ストレス, 癌幹細胞

\section{はじめに}

2003 年 4 月 14 日, ヒト遺伝子の $99 \%$ を $99.99 \%$ 以上の精度で解読したヒトゲノム計画の完全終 了が宣言された1). 基本設計図の完成によるポス トゲノム時代の幕開けから 10 年が経過し, 様々 なイノベーションが生まれている．まず高密度 マイクロアレイ技術の開発により, 全ゲノムを 包括するトランスクリプトミックスが可能となっ た. 現在では, DNAマイクロアレイによる網羅 的遺伝子発現解析は一般的な手法となっている. また, ゲノム上の個人差を示す違いを一塩基多 型 (single nucleotide polymorphism : SNP) と 呼ぶが, 国際的プロジェクトによって精度の高 いSNPパターンのデータベースも整備された (HapMap). 約 1 千万種存在するSNPの中から, 遺伝的多型を識別する代表的な $\operatorname{SNP}$ (約 50 万種)
が“タグSNP”として選別され，2005 年からイ ンターネットにより無償で情報公開されている. さらに, 遺伝子配列を解読するシーケンス技術 も飛躍的に進み, 疾患別の全ゲノムを決定する 国際プロジェクトが次々に進められている。近 年, 著しい研究成果が得られているGWAS (genome-wide association study : ゲノムワイド 関連解析）および全ゲノム（エキソン） シーケ ンス解析 (whole genome sequencing, whole exome sequencing) を中心に, 肝癌における代 表的報告をまとめ, その臨床的意義について考 察する.

\section{1. 肝癌の病因〜GWASからのアプローチ}

肝癌の背景となる慢性肝疾患として, ウイル ス性肝炎 (hepatitis B virus : HBV, hepatitis C virus : HCV), アルコール性肝炎, 非アルコー

東京医科歯科大学肝胆膵 $\cdot$ 総合外科

Liver Cancer : Progress in Diagnosis and Treatments. Topics: III. Whole genome analysis to reveal the pathogenesis of hepatocellular carcinoma.

Shinji Tanaka : Department of Hepato-Biliary-Pancreatic Surgery, Tokyo Medical and Dental University, Japan. 


\section{中·低分化型肝細胞癌 血管新生, 脈管浸潤, 転移能}

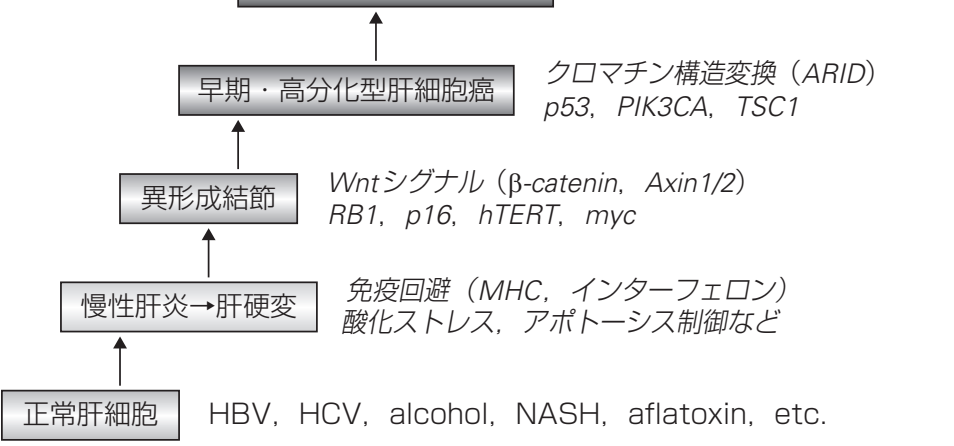

図 1. 肝癌の多段階的進展

肝細胞癌の多くは, ウイルス性肝炎 (HBV, HCV), アルコ一ル性肝炎, 非アルコ一ル性脂肪肝炎（NASH）などによる慢性肝炎・肝硬变を背 景亡して発生することが知られている. 慢性肝炎・肝硬変から発癌へ と進む遺伝的感受性は, 免疫回避, 酸化ストレス抑制, アポトーシス 制御などのパスウェイに分類できることがGWASにより明らかとなっ た.さらに, 肝癌の全ゲノムシーケンスの結果, p53/Rb, Wntシグ ナルに並ぶ第3のドライバ一変異パスウェイが見出されている. 今後 の研究によって, 各段階を登る責任遺伝子の同定が期待されている.

儿性脂肪肝炎（non-alcoholic steatohepatitis： NASH）など多様な病因が挙げられる（図 1). HBVの場合, 慢性化によって肝癌の発生危険率 は 7 倍となる.HBVウイルス量が高い症例, す なわちウイルス高複製状態が続いていることは 肝癌の危険因子であり, HBVジェノタイプによっ ても頻度が異なることが知られている. HCV 慢性化の場合, 肝癌の発生危険率は 15〜20 倍に も達し, 本邦ではC型肝硬変の年間発癌率 7〜 8\% （全世界では 1〜4\%) となっている. HCVウイル ス量やジェノタイプ1bと発癌についての相関を 認める報告がある一方, 否定的なデータもある.

肝発癌の病因には, このようなウイルス側の 因子だけではなく, 宿主側の素因, 発癌感受性 もリスク因子として重要である. 以前より HBV 慢性化とHLAタイピングなどの相関が報告され ていたが, 発癌の遺伝的素因を網羅的に解析す る手法として, 近年GWASが活用されている. GWASとは, 個人を識別するタグSNP（約 50 万種）をマーカーとして利用し, 特定の個人集
団の遺伝的背景を網羅的に采り出すものである. Zhangらは中国のHBV慢性感染者のうち, 肝 癌を持つ 348 例と持たない 359 例を比較した GWASを解析した (表). その結果, KIF1Bのイ ントロン上の遺伝子多型がHBV陽性肝癌の発癌 リスクと相関することを見出した(オッズ比 1.64 ; $\left.\mathrm{p}=2 \times 10^{-18}\right)^{2)} . \mathrm{KIF} 1 \mathrm{~B}$ 含むキネシン・ファミ リーは微小管上を移動し，様々な物を輸送する モーター蛋白質群で, 特にKIF1Bはミトコンド リアなどの細胞内輸送を担っている. KIF1Bを含 む染色体 $1 \mathrm{p} 36.2$ 領域は神経芽腫など多くの癌腫 で久失しており, アポトーシス誘導といった癌 抑制遺伝子として機能する可能性が報告されて いる. KIF1B遺伝子多型による機能変化が, HBV 発癌メカニズムと関連することが示唆されるが, 日本でのHBV肝癌では相関を認めないという 報告もある。また中国のLiらは新しいHBV肝癌 感受性遺伝子として, 6p21.32 上のHLA-DQA1/ $D R B 1$ (オッズ比 $=1.28, \mathrm{p}=5.24 \times 10^{-22}$ ) と $21 \mathrm{q} 21.3$ 上のGRIK1 (オッズ比 $=0.84, \mathrm{p}=5.24 \times 10^{-10}$ )の 
表. GWASによって同定された肝癌感受性遺伝子

\begin{tabular}{|c|c|c|c|c|c|c|c|}
\hline 病因別 & 遺伝子名 & SNP番号 & 分類 & 機能 & オッズ比 & 地域 & 文献 \\
\hline HBV肝癌 & KIF1B & rs 17401966 & $\begin{array}{l}\text { 細胞内輸送モ一ター } \\
\text { (三トコンドリア輸送 } \\
\text { など) }\end{array}$ & $\begin{array}{l}\text { アポトーシス制御 } \\
\text { など }\end{array}$ & 1.64 & 中国 & Zhang et al. \\
\hline \multirow[t]{2}{*}{ HBV肝癌 } & $\begin{array}{l}\text { HLA-DQA1/ } \\
\text { DRB1 }\end{array}$ & rs9272105 & MHCクラス & 抗原提示 & 1.28 & \multirow[t]{2}{*}{ 中国 } & \multirow{2}{*}{ Li et al. } \\
\hline & GRIK1 & rs455804 & グルタミン酸受容体 & 酸化ストレス関連 & 0.87 & & \\
\hline \multirow[b]{2}{*}{ HBV肝癌 } & HLA-DQ & rs9275319 & MHCクラスா分子 & 抗原提示 & 1.49 & \multirow[b]{2}{*}{ 中国 } & \multirow[b]{2}{*}{ Jiang et al. } \\
\hline & STAT4 & rs7574865 & $\begin{array}{l}\text { 細胞內シグナル伝達 } \\
\text { 分子 }\end{array}$ & $\begin{array}{l}\text { インターフェロン. } \\
\text { 免疫 }\end{array}$ & 1.21 & & \\
\hline HCV肝癌 & MICA & rs2596542 & $\begin{array}{l}\text { 非古典的MHCクラス } \\
\text { Ib分子 }\end{array}$ & $\begin{array}{l}\text { NK細胞による攻 } \\
\text { 撃指標 }\end{array}$ & 1.39 & 日本 & Kumar et al. \\
\hline HCV肝癌 & DEPDC5 & rs 1012068 & $\begin{array}{l}\text { G蛋白シグナル関連 } \\
\text { 分? }\end{array}$ & 膜輸送？ & 1.75 & 日本 & Miki et al. \\
\hline$(\mathrm{NASH}) *$ & PNPLA3 & rs738409 & リパーゼ活性酵素 & エネルギー代謝 & - & 米国 & Romeo et al. \\
\hline 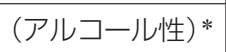 & PNPLA3 & rs738409 & リパーゼ活性酵素 & エネルギー代謝 & 2.25 & 米国 & Tian et al. \\
\hline
\end{tabular}

( ）：NASH，アルコ一ル性はそれぞれ慢性肝疾患症例を対象とした解析結果（肝癌GWAS未報告）

遺伝子多型を同定している3). GRIK1 (glutamate receptor, ionotropic, kainate 1）はグルタミン酸 受容体（イオンチャンネル共役型）の 1 つであ る.グルタミン酸は酸化ストレスを制御するグ ルタチオンの構成要素の 1 つであり, “癌幹細胞” との関連性から HBV肝発癌における重要性が推 察される.さらにJiangらは中国HBV肝癌の解析 から, $H L A-D Q$ (オッズ比 $=1.49, \mathrm{p}=2.72 \times 10^{-17}$ ) とSTAT4（オッズ比 $\left.=1.21, \mathrm{p}=2.48 \times 10^{-10}\right)$ を 同定した4). STAT4 はインターロイキン 12 やイ ンターフェロン $\alpha / \beta$ によって活性化される細胞内 シグナル分子であり,ヘルパーT細胞分化やイン ターフェロン 鏟生に重要な機能を持っている. STAT4 遺伝子多型はイントロンにあり, 肝組織 のSTAT4 低発現と相関するという結果から, 感 染・癌化メカニズムへの関与が示唆される.

HCV 慢性化のGWASでは, 我が国を含む複数 の研究グループからIL28B遺伝子多型が同定され ているが, HCV肝癌のGWASについても我が国 の 2 つの研究グループから報告されている(表). KumarらはHCV陽性肝癌 721 例, 健常者 2,890
例について約 43 万個のSNPを比較して, 6q21.3 のMICA領域を同定した (オッズ比 $=1.39, \mathrm{P}=4 \times$ $\left.10^{-13}\right)^{5)}$. MICA遺伝子多型によってMICA蛋白量 が低下することから，遺伝子プロモーター活性 の変化が示唆される. MICA (MHC class I chainrelated gene A) は非古典的MHCクラスIb分子に 属する膜蛋白の 1 つであり, ウイルス感染や癌 化した細胞表面で高発現し, NK細胞の活性型レ セプターNKG2Dに対するリガンドとして機能す る.つまり, MICA遺伝子多型により MICA蛋白 が低下すると, NK細胞によって認識されないた め, 感染 - 癌化肝細胞の排除機構が機能不全に 陥り，発癌リスクへとつながることが予想され る。一方, MikiらはHCV慢性感染のうち肝癌が 好発する 55 歳以上に対象を絞り, 肝癌を持つ 212 例と持たない 765 例に対して約 47 万個のSNP を比較して, 22q12.3 上に存在するDEPDC5 のイ ントロン領域の遺伝子多型を同定した（オッズ 比 $\left.\left.=1.75, \mathrm{p}=1.27 \times 10^{-13}\right)^{6}\right)$. DEPDC5（DEP domain-containing protein 5) は，Gタンパク質 シグナルを活性化するDEPドメインをC末端に持 
ち, 膜輸送に関与することが示唆されているが, 常染色体優性焦点性てんかんの原因遺伝子とも 報告されている. DEPDC5 遺伝子多型による発 現立進が発癌を促す可能性が予想されており, 機能解析に基づくメカニズムの解明が必須であ る.

我が国では, 非ウイルス性肝障害による肝癌 が増加している．アルコール性肝障害に加え， 糖尿病などメタボリック症候群を背景とする NASHが注目されているが, HBV潜伏感染の 存在なども指摘されており, その発癌メカニズ ムには不明な点も多い. 非ウイルス性肝障害の 中でも, NASHでは家族歴を $18 \%$ に認め, また 米国ではヒスパニック系とアフリカ系の発症リ スクが 10 倍以上異なるという報告があり, NASH 発症の遺伝的素因が示唆されている. NASH発症 に対するGWASの結果, 22q13.31 上のPNPLA3 遺伝子多型が同定され，ヒスパニック系に多い ことも証明された ${ }^{7)}$. 興味深いことにアルコー ル性肝硬変のGWASでもPNPLA3 遺伝子多型 と強い相関を認めることが報告されている8 ${ }^{8}$.

PNPLA3 (patatin-like phospholipase domaincontaining protein 3 : 別名adiponutrin)はリパー ゼ活性を持つ酵素であり，トリグリセロールの 加水分解, 脂肪酸の脂質間移動を介してエネル ギー代謝を促す。PNPLA3 遺伝子多型によるア ミノ酸置換によってリパーゼ活性が低下すると, 肝細胞への中性脂肪蓄積が立進されることが示 唆される.PNPLA3 遺伝子多型がNASH, アルコー ル性だけでなくウイルス性肝癌の発癌リスクや 予後にも関与するという報告があり ${ }^{9)}, \mathrm{NASH}$ 肝癌, アルコール性肝癌の各症例群を対象とし た癌特異的GWAS解析が急務である.

以上, 各病因における肝癌GWASの報告を表 にまとめた，慢性肝炎・肝硬変から発癌へと進 む遺伝的感受性は病因によって異なるが, 免疫 回避 (MHC, インターフェロンなど), 酸化スト レス抑制，アポトーシス制御などのパスウェイ
に分類できる可能性が示されている.

\section{2. 肝癌の病態〜全ゲノムシーケンスに よって解明された第 3 のパスウェイ}

癌の本体は遺伝子異常であり, 様々な変異が 癌の病態を決定するドライバーとなっている. 肝癌における遺伝子変異では癌抑制遺伝子p53 (TP53) やp16 (CDKN2A) をはじめ, $\beta$-catenin （CTNNB1）やAxinなどWntシグナル伝達パス ウェイの構成分子の変異が報告されてきた（図 2). 近年, 次世代シーケンサーなど遺伝子解析 技術の開発が急速に発展し, 癌細胞のゲノムに 存在する遺伝子変異の全体像を探るプロジェク トが進んでいる．肝癌でも全ゲノムシーケンス や全エキソンシーケンスが進行しており, 興味 深い知見が得られている.

肝癌ではゲノム全体で 1 万以上の遺伝子変異 が認められているが，実際に病態に関与するド ライバー（運転手）変異はその一部であり，多 くはパッセンジャー (乗客) 変異と考えられて いる．全ゲノムシーケンスの結果, まず既知の パスウェイにおけるドライバー変異として, p53/ $\mathrm{Rb}$ 細胞周期系 (TP53, CDKN2A) 20\%〜30\%,

Wntシグナル系 (CTNNB1, Axin1) 30\%〜40\% が共通に認められ, その他PI3K/Rasシグナル系 (PTEN, PIK3CA, TSC1, KRAS, NRAS) を数\%〜 $10 \%$ 程度検出している。

新規の HCCドライバー変異としては, 米国 $\mathrm{Li}$ らの全エキソンシーケンスによって報告された ARID2 不活化が挙げられる ${ }^{10)}$. ARID2 はSWI/ $\mathrm{SNF}$ ロマチン構造変換（リモデリング）分子 複合体のコンポーネントの1つである. DNA はヒストンを核にして巻き付くクロマチン構造 によって収納されているが, SWI/SNF複合体は クロマチン構造をほどき転写活性化を促すATP 駆動モーターである.SWI/SNF複合体は, ATPase活性をもつ酵素サブユニット (BRM, BRG1) 
A

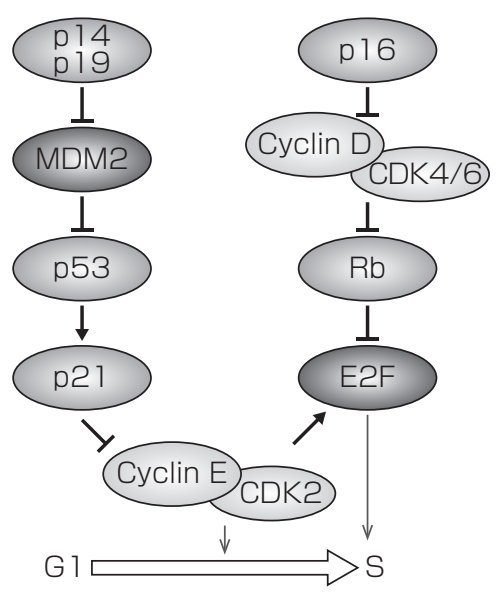

B

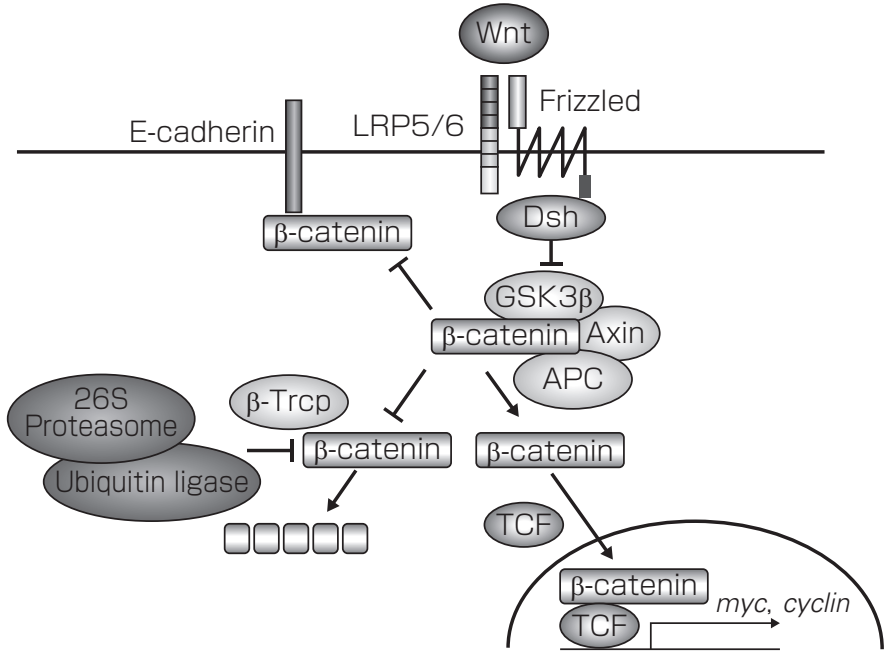

図 2. 肝癌の代表的なドライバ一変異パスウェイ

A. p53/Rb細胞周期パスウェイ. B. Wntシグナル（古典的）パスウェイ.

Guichardらの報告によると (フランス), 肝癌における遺伝子変異として, p53 (TP53) =20.8\%,

p16 $($ CDKN2A $)=7.2 \%$, および $\beta$-catenin $(C T N N B 1)=32.8 \%, A x i n 1=15.2 \%, \quad A P C=1.6 \%$ に認 められている11).

A. BAF型SWI/SNF複合体

酵素サブユニット

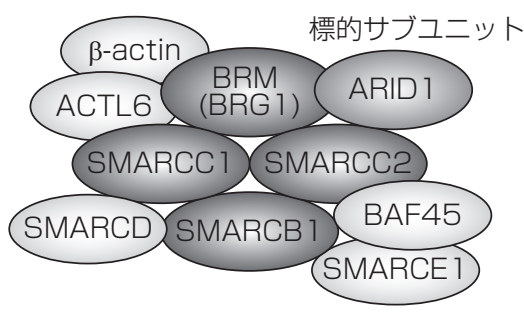

B. PBAF型SWI/SNF複合体

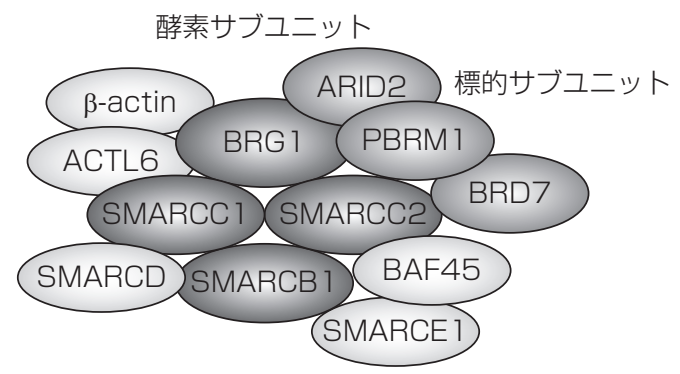

図 3. SWI/SNFクロマチン構造変換分子複合体.

A. BAF (SWI/SNF-A) 型, B. BAF (SWI/SNF-B) 型.

Fujimotoらによる本邦の報告では肝癌における遺伝子变異や欠失として，ARID1A=10\%, $A R I D 1 B=6.7 \%, A R I D 1 B=5.8 \%$ こ認められている12)

や標的サブユニットなど 10 個以上の分子群から 構成されており，近年多くの癌でその異常が報 告されている. SWI/SNF複合体には, ARID1A またはARID1Bを標的サブユニットとするBRG1associated factor (BAF) 型と, Polybromol (PBRM1)-ARID2-BRD7 を標的サブユニットとす
るPolybromo-BAF (PBAF) 型の 2 種類が知ら れており,BAF型かPBAF型かのいずれかを持っ ている（図 3)。Liらの報告では, 特にHCV肝癌 でPBAF型のARID2 不活化変異が多いとしてい る点は興味深い $(18.2 \%)$. フランスのGuichard らはアルコール性肝癌におけるARID2 変異が 


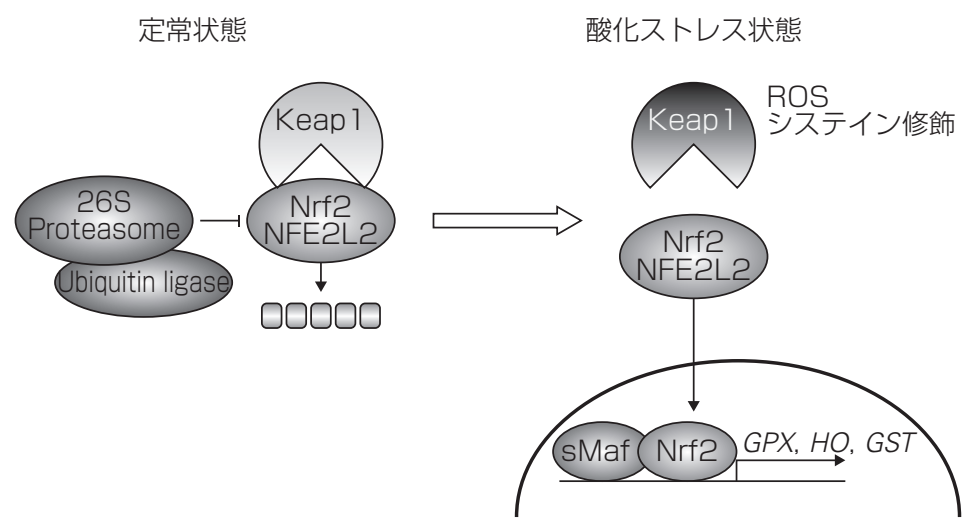

図 4. Keap 1-Nrf2 (NFE2L2) システムによる酸化ストレス応答. Keap 1 蛋白は酸化ストレスセンターとして機能する. 定常状態では, Keap 1 は転写因子Nrf2（NFE2L2）と細胞内で結合し, プロテアソー ムによるNrf2 (NFE2L2) 分解を促している. 酸化ストレス状態では, 活性酸素種 (reactive oxygen species: ROS) によってKeapl蛋 白がシステイン修飾を受けるため, その立体構造が変化してNrf2 (NFE2L2) との結合能を失う. プロテアソームの分解を免れたNrf2 (NFE2L2) は核内移行し, 抗酸化酵素群遺伝子のプロモーターに結合し て発現を促進する.

Guichardらの報告によると (フランス), 肝癌の 6.4\%にNrf2 (NER2L2) の遺伝子変異を検出し, 追加解析症例ではKEAP1にも変異を認めている11).

$5.6 \%$ に対して, BAF型のARID1A変異は $16.8 \%$ と報告しており ${ }^{11)}$, 同じパスウェイでありながら, 病因によってBAF型，PBAF型に分かれる可能 性もある.但し, Fujimotoらによる本邦の報告で は病因による差は余り明確ではなく, 肝癌全体 での遺伝子変異や久失は ARID $1 A$ 10\%, ARID1B $6.7 \%, A R I D 1 B 5.8 \%$ としている ${ }^{12)}$. さらに, 頻 度は少ないながらBRM, BRG1, PBRM1 などの 変異も肝癌で認められ, このSWI/SNFパスウェ イが $533 / \mathrm{Rb}$ パスウェイ, Wntシグナルパスウェ イに匹敵する第 3 のHCCドライバー変異として クローズアップされてきた. SWI/SNF複合体以 外にも, ヒストンをメチル化する trithorax group の一員MLLファミリーの変異を認め $(M L L$; $1.7 \%, M L L 3 ; 4.2 \%)$, また中国HBV肝癌の全ゲ ノムシーケンスでもHBV DNAの遺伝子組み込み 好発部位としてMLL4 が同定されている ${ }^{13)}$.クロ マチン構造変換分子群のドライバー変異は肝癌
全体の $50 \%$ 以上に認められ, それによって惹起 されるエピゲノム制御システムの異常が, 肝癌 の病態に深く関与していることが示唆される ${ }^{12}$.

\section{3. 酸化ストレスから見た肝癌の特徴}

フランスのGuichardらによる報告では, 肝癌 の $6.4 \%$ にNFE2L2 の活性化変異を検出してい る ${ }^{11)}$. NFE2L2 は塩基領域ロイシンジッパー構造 を持つ転写因子Nrf2 をコードしており,グルタ チオン合成酵素, グルタチオンペルオキシダー ゼ，へムオキシダーゼなど一連の抗酸化酵素群 に対して強力な転写活性を示し, 酸化ストレス 応答のキー因子の 1 つとして知られている（図 4). Nrf2 は通常, ユビキチンリガーゼE3 複合体 の基質認識アダプター蛋白Keap1 と細胞内で結 合しプロテアソームによって次々に分解されて いるが, 細胞内活性酸素によってKeap1 蛋白が 
修飾されると立体構造が変化し, Nrf2(NFE2L2) を放出する. プロテアソームの分解を免れたNrf2 (NFE2L2) は核内移行し, 抗酸化酵素群遺伝子 のプロモーターに結合して強発現を促進する. 肝癌ではNFE2L2 活性化変異以外にもKeap1 不活 化変異を認めており, 興味深いことに全てWnt シグナル系活性化変異を伴っていた ${ }^{11)}$. 肝癌にお ける酸化ストレス代謝と, Wntシグナルの相互作 用を示唆する新しい知見である.

酸化ストレス抑制は，前述したように癌幹細 胞のみならず幹細胞に備わった特性の 1 つと考 えられている。 また癌細胞はタンパク合成が活 発であり一般にプロテアソーム活性の立進を認 めるのに対して, 未分化幹細胞ではプロテアソー 厶活性が低く維持されている。 そこで我々は, 肝癌細胞集団の中からプロテアソーム活性が低 く, かつ細胞内活性酸素が低いサブグループを 視覚化して, 単離・解析を試みた ${ }^{14)}$. その結果, この細胞分画は非対称性分裂を呈し幹細胞マー カーを持つこと, 低酸素下で抗癌剤抵抗性を示 し高い造腫瘍性と転移能を持つことが判明し， いわゆる肝癌幹細胞の性質を呈することを明ら かとなった

我々が単離した肝癌幹細胞を用いて，DNA マイクロアレイによる特異的遺伝子シグネチャー を解析すると, ケモカイン・ネットワークが異 常㐫進していることを見出した. 実際, in vitro ではマクロファージ遊走能を呈し, in vivo転移組 織の解析では肝癌幹細胞の周囲にマウスマクロ ファージが集簇することを確認し，生体内にお けるニッチ環境の特異性が示された。 さらに肝 癌幹細胞の遺伝子シグネチャーを用いて, 肝癌 切除検体のDNAマイクロアレイデータと照合し てみると, 肝癌幹細胞遺伝子シグネチャーを呈 した肝癌症例は有意に早期再発することが明ら かとなった ${ }^{14)}$. 幹細胞特性に基づいた解析は, 肝 癌の臨床病態の解明へ展開できることが示唆さ れた。

\section{おわりに}

一方酸化ストレスは, 肝発癌の危険因子とし て重要であることも知られている. 我々は多症 例のDNAマイクロアレイ解析の結果, 早期肝癌 における治癒切除後の再発が, 癌部遺伝子では なく非癌部の酸化ストレス遺伝子シグネチャー のみによって規定されることを報告した ${ }^{15)}$. 酸化 ストレス状態は, ゲノム不安定性を促して発癌 のイニシエーターとなるばかりでなく, ゲノム 不安定性がさらに多様性を誘導して悪性化を促 すという癌進展のプロモーターとしても働く． このような悪性スパイラルの中で，逆に酸化ス トレスを抑制する能力を維持するサブグループ が，癌幹細胞として機能すると考えられる．肝 癌は多様な病因, 病態を示す疾患であるが, 多 様性を生む根幹である癌幹細胞は, 転移や再発 など癌難治性の要因でもある，肝癌の全ゲノム 解析は未だ緒に就いたばかりであり, 癌の本態 を解明するため, 臨床に則した多様な視点から の解析が急務となっている。

著者のCOI (conflicts of interest) 開示：本論文発表内容に 関連して特に申告なし

\section{文献}

1) Collins FS, et al : A vision for the future of genomics research. Nature 422 (6934) : 835-847, 2003.

2) Zhang H, et al: Genome-wide association study identifies 1 p36.22 as a new susceptibility locus for hepatocellular carcinoma in chronic hepatitis B virus carriers. Nat Genet 42 (9) : 755-758, 2010.

3) Li S, et al : GWAS identifies novel susceptibility loci on 6p21.32 and 21q21.3 for hepatocellular carcinoma in chronic hepatitis B virus carriers. PLoS Genet 8 (7) : e1002791, 2012.

4) Jiang DK, et al : Genetic variants in STAT4 and HLA-DQ genes confer risk of hepatitis B virus-related hepatocellular carcinoma. Nat Genet 45 (1) : 72-75, 2013.

5) Kumar V, et al : Genome-wide association study identifies a susceptibility locus for HCV-induced hepatocellular carcinoma. Nat Genet 43 (5) : 455-458, 2011. 
6) Miki D, et al:Variation in the DEPDC5 locus is associated with progression to hepatocellular carcinoma in chronic hepatitis C virus carriers. Nat Genet 43(8) : 797-800, 2011.

7) Romeo S, et al: Genetic variation in PNPLA3 confers susceptibility to nonalcoholic fatty liver disease. Nat Genet 40 (12) : 1461-1465, 2008.

8) Tian C, et al : Variant in PNPLA3 is associated with alcoholic liver disease. Nat Genet 42 (1) : 21-23, 2012.

9) Hassan MM, et al : Genetic variation in the PNPLA3 gene and hepatocellular carcinoma in USA:Risk and prognosis prediction. Mol Carcinog 2013, in press.

10) Li M, et al: Inactivating mutations of the chromatin remodeling gene ARID2 in hepatocellular carcinoma. Nat Genet 43 (9) : 828-829, 2011.

11) Guichard $C$, et al : Integrated analysis of somatic mutations and focal copy-number changes identifies key genes and pathways in hepatocellular carcinoma. Nat
Genet 44 (6) : 694-698, 2012.

12) Fujimoto A, et al: Whole-genome sequencing of liver cancers identifies etiological influences on mutation patterns and recurrent mutations in chromatin regulators. Nat Genet 44 (7) : 760-764, 2012.

13) Sung WK, et al : Genome-wide survey of recurrent HBV integration in hepatocellular carcinoma. Nat Genet 44(7) : 765-769, 2012.

14) Muramatsu S, et al : Visualization of stem cell features in human hepatocellular carcinoma reveals in vivo significance of tumor-host interaction and clinical course. Hepatology 58 (1) : 218-228, 2013.

15) Tanaka $\mathrm{S}$, et al: Oxidative stress pathways in noncancerous human liver tissue to predict hepatocellular carcinoma recurrence; a prospective multi-center study. Hepatology 54 (4) : 1273-1281, 2011. 